\title{
INCOME EFFECTS OF INVESTMENTS AND WAGES WHEN SAVING RATES DIFFER*
}

\author{
by \\ FRITZ HELMEDAG \\ Technische Universität Chemnitz
}

\begin{abstract}
Macroeconomic reasoning often postulates a uniform saving rate. Yet, this approach is only consistent with two special cases: either all households spend the same fraction of earnings or the shares in national income are held constant by assumption. Both premises lead astray. It is shown that fluctuations in investments (as a synonym for autonomous demand) generally affect distribution. In addition, the impacts of a changing wage bill on domestic product ('purchasing power argument') or profits ('wage-profit trade-off') are revealed.
\end{abstract}

\section{Effective Demand in Short Supply}

Standard textbooks on macroeconomics lack a profound analysis of the mutual relationships between income and expenditures. Accordingly, a full explanation of the circular flow is missing. Thus, a fundamental question of the field is blended out: how are the decrease in net funds ('investment') of some subjects and the accumulation of pecuniary wealth ('saving') of others connected? The problem arises because all payments turn completely into earnings, but the received money will be spent neither entirely every time nor always to 100 per cent in the real sector of the economy.

Disciples of the prevailing approach rest their expositions on the opposing forces of supply and demand; that is to say, they apply their usual microeconomic tools to tackle macroeconomic issues. Consequently, the flow-balance conditions are largely neglected. In so far as multiplier effects appear, they are restricted to simple income-expenditure exercises, where uniform saving rates are presupposed. ${ }^{1}$ The subsequent analysis uncovers that the popular depictions do not merely oversimplify matters; more severely, they misinform in principle.

In the present paper we deal with the impact of spending decisions and the wage bill on the nominal values of domestic product and profits, i.e. amounts of money per period of time. ${ }^{2}$ In this respect, the "purchasing power argument' deserves scrutiny. It is quite often put forth by trade unions'

* Manuscript received 2.2.07; final version received 21.2.08.

$\dagger$ Valuable comments by two anonymous referees are gratefully acknowledged. The usual caveats apply.

${ }^{1}$ See, for example, Blanchard (2003), Carlin and Soskice (2006) and Mankiw (2006).

${ }^{2}$ It seems reasonable to suppose that in phases of underemployment and fierce competition a rise in national income more likely affects quantities than prices. In the following, however, this is not a point at issue. 
representatives who claim that an increase in total pay raises sales and, therefore, the demand for labour. In contrast, employers resort to a 'wageprofit trade-off' reasoning. They spread the opinion that a higher remuneration causes lower profits whence capital accumulation will be dampened. In the end, aggregate output would decrease.

Finally, it is established under which circumstances changing investments leave the distribution and the average saving rate unaltered. Only in exceptional cases can the dominant doctrine claim to tell the truth. ${ }^{3}$

The models belong to the short run in so far as long-run aspects of the propensity to consume, the development of labour supply and productivity etc. are ignored. The applied method is comparative static since 'provisional' equilibria (see Chick and Caserta, 1997) are juxtaposed which serves a particular theoretical purpose: to determine the income effects of investments or rather the wage bill.

The setting is quite simple. The economy under consideration is assumed to be closed and the government does not perform any economic activity. Capacity utilization ${ }^{4}$ is not discussed because only nominal values occur. Merely two types of spending are distinguished: on the one hand, the households' consumption as a fraction of income and, on the other hand, exogenous expenditures called 'investments'. ${ }^{5}$ This catch-all parameter, perhaps reflecting 'animal spirits' or the state of business confidence, comprises the various kinds of autonomous demand, financed either by cash, the liquidation of assets or borrowing.

Within this framework, three models are presented. In the first setting, society's consumption is determined by a uniform saving rate. Next, specific spending habits for workers and capitalists are introduced. ${ }^{6}$ Saving patterns are class-specific and do not refer to the sources of income, i.e. workers follow a uniform propensity to consume even if they earn a part of profits. In the third step, the two groups receive profits according to their respective savings. For each of the three alternative set-ups, nominal national income and its distribution are calculated. In addition, the effects of changing investments and wages are ascertained.

\section{Equal Consumption Patterns}

Usually $s$ denotes the saving rate. Yet, the standard literature fails to impart whether this symbol indicates the saving rate of identical households or the weighted average of class-specific ones. In the latter case, $s$ inevitably varies

${ }^{3}$ A somewhat different German version of this study has been published in Helmedag (2005).

${ }^{4}$ Meanwhile there exists a body of literature on this topic, which is central in a Kaleckian line of argument. See, for example, Blecker (2002) and Hein (2006).

${ }^{5}$ Akerlof (2007, pp. 13 et seq.) makes a strong case for the 'Keynesian' consumption function used here. Particular investment functions are examined by Lavoie (1995).

${ }^{6}$ With in regard to the history of post-Keynesian theory, see King (2002) and Harcourt (2006). 
with the distribution of income. Since textbooks do not offer this interpretation, their world seems to be populated by households that share a common propensity to save with $0<s \leq 1$.

Then, total consumption $C$ in money terms amounts to $C_{1}=(1-s) Y_{1}$, where $Y_{1}$ stands for national income. ${ }^{7}$ Because the government and the rest of the world are not involved here, only investments $(I)$ representing autonomous demand have to be considered. Equating the value of aggregate output and total expenditure gives $Y_{1}=C_{1}+I$. Inserting the households' consumption in this expression yields

$$
Y_{1}=\frac{I}{S}
$$

Independent of wages, a rise in investments will entail a higher equilibrium domestic product. The 'simple' multiplier relation reads

$$
\frac{\mathrm{d} Y_{1}}{\mathrm{~d} I}=\frac{1}{S}
$$

It is possible to establish a link between the money values of the wage bill $(W)$ and (gross) profits $(P)$. By definition, the latter consist of the difference between (ex post realized) national income and the (ex ante contracted) remuneration for the labour power:

$$
P_{1}=Y_{1}-W
$$

From an economic perspective, however, the two income components are not on equal footing. Under capitalistic conditions, aggregate wages generally do not suffice to purchase the domestic product. Expenditures stemming from other sources must appear so that profits arise: 'However great the margin of profit on a unit of output, the capitalists cannot make more in total profits than they consume and invest (inclusive of accumulation of unsold goods)' (Kalecki, 1942, p. 260).

Combining equations (1) and (3) leads to

$$
P_{1}=\frac{I-s W}{s}
$$

As a consequence, positive profits require that autonomous demand exceed the savings out of wages:

$$
P_{1}>0 \Leftrightarrow I>I_{1}:=s W
$$

Contrary to the commonly held individualistic view, investments generate entrepreneurial income on the macroeconomic level.

Whenever the wage bill increases, profits decrease by the same amount in the present scenario. Equation (4) verifies this statement. The impact of a

${ }^{7}$ The index refers to the corresponding model. 
varying pay on profits expresses the widespread idea of an existing one-to-one trade-off between the income categories: ${ }^{8}$

$$
\frac{\partial P_{1}}{\partial W}=-1
$$

Because the domestic product is determined by $s$ and $I$ alone, wages do not affect the value of output. Hence, an augmented pay causes an equal reduction in profits. In this case, the fight for income shares tends to be extremely fierce.

Equation (4) also provides information on how an investment variation alters profits:

$$
\frac{\mathrm{d} P_{1}}{\mathrm{~d} I}=\frac{1-s \frac{\mathrm{d} W}{\mathrm{~d} I}}{s}=\frac{\mathrm{d} Y_{1}}{\mathrm{~d} I}-\frac{\mathrm{d} W}{\mathrm{~d} I}
$$

Dividing profits (4) by domestic product (1) gives

$$
\frac{P_{1}}{Y_{1}}=1-\frac{s W}{I}
$$

To keep the share of the profits in income constant, a very special condition is required. From

$$
\frac{\mathrm{d}\left(\frac{P_{1}}{Y_{1}}\right)}{\mathrm{d} I}=\frac{-s\left(\frac{\mathrm{d} W}{\mathrm{~d} I} I-W\right)}{I^{2}}=0
$$

immediately follows

$$
\frac{\mathrm{d} W}{\mathrm{~d} I}=\frac{W}{I} \Leftrightarrow \frac{\mathrm{d} W}{W}=\frac{\mathrm{d} I}{I}
$$

National income and its components change with the same percentage if and only if total wages and autonomous demand grow at the same rates. This coincidence can be regarded as highly improbable. In a capitalist society, the right-hand side of the first equation in expression (9) is always positive since the system is founded on wage labour. Rising investments, however, have no predetermined (final) effect on the payroll. For example, the construction of additional manufacturing facilities raises the remuneration of the workers. In contrast, it is also possible that labour-saving installations reduce their income, i.e. $\mathrm{d} W / \mathrm{d} I<0$. Indeed, cost minimization drives the choice of technique. Finally, a variation of exogenous demand can even be without impact on total wages. This is conceivable in cases of excess capacity, when more or

\footnotetext{
${ }^{8}$ In order to indicate symbolically that investments may be indirectly affected by a changing wage bill, the partial derivative is used. If necessary, such repercussions are amenable to the multiplier analysis expounded below.
} 
less output is produced with the same staff. In such situations, fluctuations in autonomous expenditures are completely reflected in profits that change domestic product by the same amount.

At any rate, condition (9) either cannot be fulfilled or can be fulfilled only by some amazing fluke. Most likely, investments alter the share of profits in national income. Thus, the saving rate of the standard model should not be interpreted as a given average. Consequently, in the multiplier process the 'community's propensity to consume' (Keynes, 1936, p. 27) varies. All the more in face of the fact that the assumption of a uniform saving rate across all households has no solid underpinning, ${ }^{9}$ a more fruitful approach appears necessary.

\section{Class-specific Expenditures}

According to the 'fundamental psychological law' (Keynes, 1936, p. 96) the propensity to consume falls with a growing personal income. If capitalists receive a relatively high per-capita income, their saving rate $\left(s_{\mathrm{P}}\right)$ will be larger than the workers' one $\left(s_{\mathrm{W}}\right)$ :

$$
0 \leq s_{\mathrm{W}}<s_{\mathrm{P}} \leq 1
$$

Aggregate consumption is determined by $C_{2}=\left(1-s_{\mathrm{W}}\right) W+\left(1-s_{\mathrm{P}}\right) P_{2}$, and the domestic product becomes $Y_{2}=\left(1-s_{\mathrm{W}}\right) W+\left(1-s_{\mathrm{P}}\right)\left(Y_{2}-W\right)+I$. Solving this equation for $Y_{2}$ yields

$$
Y_{2}=\frac{I+\left(s_{\mathrm{P}}-s_{\mathrm{W}}\right) W}{s_{\mathrm{P}}}
$$

Contrary to model 1 , the national income now depends on the wage bill. An increment in pay implies a higher domestic product as long as investment remains unaffected:

$$
0 \stackrel{(10)}{<} \frac{S_{\mathrm{P}}-s_{\mathrm{W}}}{S_{\mathrm{P}}} \stackrel{(11)}{=} \frac{\partial Y_{2}}{\partial W} \leq 1
$$

Under such circumstances, the purchasing power argument applies in principle. Naturally, national income forms the upper limit on the wage bill.

Profits amount to

$$
P_{2}=Y_{2}-W=\frac{I+\left(s_{\mathrm{P}}-s_{\mathrm{W}}\right) W}{s_{\mathrm{P}}}-W \geq 0
$$

Rewriting creates more clarity:

\footnotetext{
${ }^{9}$ For example, in 2003 the saving rate for the low-income decile in Germany was negative whereas the 1 per cent of top earners reached nearly 40 per cent (see Klär and Slacalek, 2006, p. 541). 


$$
P_{2}=\frac{I-s_{\mathrm{W}} W}{s_{\mathrm{P}}}
$$

Equation (13) states that profits can be increased by a higher autonomous demand and less savings. Kaldor put it in a nutshell: '[. . .] Keynes regards entrepreneurial incomes as being the resultant of their expenditure decisions, rather than the other way round-which is perhaps the most important difference between "Keynesian" and "pre-Keynesian" habits of thought' (Kaldor, 1955/56, p. 94, note).

In this scenario, profits are positive whenever investments exceed workers' savings:

$$
P_{2}>0 \Leftrightarrow I>I_{2}:=s_{\mathrm{W}} W
$$

The profit function (13) describes the relation between wages and profits. Forming the partial derivative of profits with respect to the wage bill yields $\partial P_{2} / \partial W=-s_{\mathrm{W}} / s_{\mathrm{P}}$. Due to condition (10), the range of the 'reaction coefficient' is

$$
-1<\frac{\partial P_{2}}{\partial W}=-\frac{s_{\mathrm{W}}}{S_{\mathrm{P}}} \leq 0
$$

This economy seems to be a more harmonious place than the one of model 1 . Apparently, increasing wages do not require equally decreasing profits as before. For $s_{\mathrm{P}}>2 s_{\mathrm{W}}$, higher wages cause the domestic product to rise by an amount larger than the corresponding decline in profits. In this respect, the struggle over income distribution may be regarded as 'productive'.

Next on the agenda is multiplier analysis. Differentiating equation (11) with respect to autonomous demand results in

$$
\frac{\mathrm{d} Y_{2}}{\mathrm{~d} I}=\frac{1+\left(s_{\mathrm{P}}-s_{\mathrm{W}}\right) \frac{\mathrm{d} W}{\mathrm{~d} I}}{s_{\mathrm{P}}}
$$

Unexpectedly, domestic product does not always grow with investments. When labour is substituted by machinery, $Y_{2}$ falls as long as

$$
\left(s_{\mathrm{P}}-s_{\mathrm{W}}\right) \frac{\mathrm{d} W}{\mathrm{~d} I}<-1
$$

Equation (13) offers information about the profit response:

$$
\frac{\mathrm{d} P_{2}}{\mathrm{~d} I}=\frac{1-s_{\mathrm{W}} \frac{\mathrm{d} W}{\mathrm{~d} I}}{s_{\mathrm{P}}}
$$

Once more, an additional autonomous demand surprisingly compresses profits in situations where 


$$
s_{\mathrm{W}} \frac{\mathrm{d} W}{\mathrm{~d} I}>1
$$

It is instructive to find the proviso which makes the average rate of savings independent of investments. After some obvious manipulations the equation

$$
s_{2}=s_{\mathrm{W}} \frac{W}{Y_{2}}+s_{\mathrm{P}} \frac{P_{2}}{Y_{2}}
$$

turns into

$$
s_{2}=\frac{s_{\mathrm{P}} I}{I+\left(s_{\mathrm{P}}-s_{\mathrm{W}}\right) W}
$$

Regularly, the level of investments affects the average saving rate. The exception requires

$$
\frac{\mathrm{d} s_{2}}{\mathrm{~d} I}=\frac{s_{\mathrm{P}}\left[W\left(s_{\mathrm{P}}-s_{\mathrm{W}}\right)-I \frac{\mathrm{d} W}{\mathrm{~d} I}\left(s_{\mathrm{P}}-s_{\mathrm{W}}\right)\right]}{\left[I+W\left(s_{\mathrm{P}}-s_{\mathrm{W}}\right)\right]^{2}}=0
$$

Again, investments exert no influence on the average saving rate provided that $\mathrm{d} W / \mathrm{d} I=W / I$. Amazingly enough, condition (9) must hold strictly even in this model to ensure that income shares and, thus, the average saving rate remain invariant in the multiplier process. Outside this exceptional state, it is a priori unclear whether the share of profits will move in the same direction or in the opposite direction as autonomous demand. Yet, owing to labour costs curbing process innovations, i.e. for $\mathrm{d} W / \mathrm{d} I<0$ in equations (16) and (17), profits rise to a larger extent than domestic product, which may even shrink.

\section{Profitable Savings}

It is plausible that employees do not simply hoard their unspent income. Rather, they also strive for some return on investment. Pasinetti (1962) postulated a division of profits between workers $\left(P_{\mathrm{W}}\right)$ and capitalists $\left(P_{\mathrm{P}}\right)$ equal to the ratio of their respective savings. ${ }^{10}$ Once this premise is accepted, from

$$
\frac{P_{\mathrm{P}}}{P_{\mathrm{W}}}=\frac{s_{\mathrm{P}} P_{\mathrm{P}}}{s_{\mathrm{W}}\left(W+P_{\mathrm{W}}\right)}
$$

it follows that

$$
P_{\mathrm{W}}=\frac{s_{\mathrm{W}} W}{s_{\mathrm{P}}-s_{\mathrm{W}}}
$$

\footnotetext{
${ }^{10}$ Pasinetti's analysis has been intensively debated; the discussion is reviewed by Ahmad (1991, Ch. 13). 
A higher workers' saving rate raises their profits relative to the remuneration for labour services as long as $s_{\mathrm{W}}<s_{\mathrm{P}}$ (see Bortis, 1993, p. 109). In total, they get

$$
W+P_{\mathrm{W}}=W\left(1+\frac{s_{\mathrm{W}}}{s_{\mathrm{P}}-s_{\mathrm{W}}}\right)=\frac{s_{\mathrm{P}} W}{s_{\mathrm{P}}-s_{\mathrm{W}}}
$$

Given the income of workers and capitalists, national consumption reads

$$
\begin{aligned}
C_{3} & =\left(1-s_{\mathrm{W}}\right) \frac{s_{\mathrm{P}} W}{s_{\mathrm{P}}-s_{\mathrm{W}}}+\left(1-s_{\mathrm{P}}\right)\left(Y_{3}-\frac{s_{\mathrm{P}} W}{s_{\mathrm{P}}-s_{\mathrm{W}}}\right) \\
& =s_{\mathrm{P}} W+\left(1-s_{\mathrm{P}}\right) Y_{3}=Y_{3}-s_{\mathrm{P}} P_{3}
\end{aligned}
$$

Adding investments yields the entire expenditure: $Y_{3}=C_{3}+I=Y_{3}-s_{\mathrm{P}} P_{3}+I$. Solving this expression for aggregate profits results in

$$
P_{3}=\frac{I}{S_{\mathrm{P}}}
$$

Apparently, profits arise when investments are positive independent of the workers' saving rate. Although the employees obtain unearned income, the sum of profits in this economy hinges exclusively on the capitalists' decisions. Accordingly, no wage-profit trade-off exists in this setting. Profits remain unchanged by wage bill variations:

$$
\frac{\partial P_{3}}{\partial W}=0
$$

National income is calculated with recourse to the profit function (22):

$$
Y_{3}=P_{3}+W=\frac{I+s_{\mathrm{P}} W}{s_{\mathrm{P}}}
$$

It can directly be seen that

$$
\frac{\partial Y_{3}}{\partial W}=1
$$

If both classes of society receive profits, the purchasing power argument applies in the strictest sense. Profits accruing to capitalists amount to

$$
P_{\mathrm{P}}=P_{3}-P_{\mathrm{W}}=\frac{I}{S_{\mathrm{P}}}-\frac{s_{\mathrm{W}} W}{S_{\mathrm{P}}-s_{\mathrm{W}}}
$$

This equation portrays the logic of the process in which the profits are generated and allocated. Basically, the entrepreneurs alone determine the level of entire profits via $I$ and $s_{\mathrm{P}}$. The workers participate by performing a specific saving behaviour. For $0<s_{\mathrm{W}}<s_{\mathrm{P}}$, positive capitalists' profits call for a higher autonomous demand $I_{3}$ than before: 


$$
I_{3}>\frac{s_{\mathrm{P}} S_{\mathrm{W}} W}{s_{\mathrm{P}}-s_{\mathrm{W}}} \stackrel{(14)}{=} \frac{s_{\mathrm{P}}}{s_{\mathrm{P}}-s_{\mathrm{W}}} I_{2}>I_{2}
$$

From domestic product (24), the effect of an investment variation on output is derived:

$$
\frac{\mathrm{d} Y_{3}}{\mathrm{~d} I}=\frac{1+s_{\mathrm{P}} \frac{\mathrm{d} W}{\mathrm{~d} I}}{s_{\mathrm{P}}}
$$

The previous model has taught that an expanding autonomous demand will not necessarily raise national income. The same holds true in the present framework. Whenever $\mathrm{d} W / \mathrm{d} I<-1 / s_{\mathrm{P}}$ the numerator of (28) becomes negative. Yet, according to equation (22) aggregate profits always increase:

$$
\frac{\mathrm{d} P_{3}}{\mathrm{~d} I}=\frac{1}{S_{\mathrm{P}}}
$$

Again the question arises, how to isolate the average rate of savings from fluctuations in investments. Substituting equations (21), (24) and (26) in

$$
s_{3}=s_{\mathrm{W}} \frac{W+P_{\mathrm{W}}}{Y_{3}}+s_{\mathrm{P}} \frac{P_{\mathrm{P}}}{Y_{3}}
$$

leads to

$$
s_{3}=\frac{s_{\mathrm{P}} I}{I+s_{\mathrm{P}} W}
$$

Remarkably, the saving behaviour of the workers does not contribute to the average saving rate here. The condition for its constancy requires

$$
\frac{\mathrm{d} s_{3}}{\mathrm{~d} I}=\frac{s_{\mathrm{P}}^{2}\left(W-I \frac{\mathrm{d} W}{\mathrm{~d} I}\right)}{\left(I+s_{\mathrm{P}} W\right)^{2}}=0
$$

Once more, the proviso $\mathrm{d} W / \mathrm{d} I=W / I$ must hold true, which hardly ever happens. Otherwise, income shares and the average saving rate are connected to investments and cannot be considered as given. Moreover, in this model a possible 'contraction setting' should be noted. Inspecting (26) reveals

$$
\frac{\mathrm{d} P_{\mathrm{P}}}{\mathrm{d} I}=\frac{1}{S_{\mathrm{P}}}-\frac{s_{\mathrm{W}}}{S_{\mathrm{P}}-s_{\mathrm{W}}} \frac{\mathrm{d} W}{\mathrm{~d} I}
$$

The second term on the right-hand side of equation (32) reflects the alteration of the workers' profit (20) due to a changing investment. Thus, if

$$
\frac{\mathrm{d} W}{\mathrm{~d} I}>\frac{s_{\mathrm{P}}-s_{\mathrm{W}}}{S_{\mathrm{P}} S_{\mathrm{W}}}
$$


the repercussion on the capitalists' profit is negative. Paradoxically, augmenting autonomous demand diminishes their income. The efforts to offset such losses intensify the entrepreneurs' urge to control costs. If the capitalists succeed in reducing the wage bill by means of labour-saving technical progress, their profits soar whereas domestic product possibly declines. This, in return, aggravates the battle over distribution.

\section{Differences Matter}

Table 1 appears useful to summarize the findings of this enquiry. The first four rows display the equations for national income and profits together with the respective multiplier formulae. All concepts substantiate the Keynesian view: profits occur only if investments exceed a certain minimum.

For differing consumption patterns, the average saving rates presented in row five depend both on the wage bill and on autonomous expenditures. A

TABLE 1

A Survey of Results

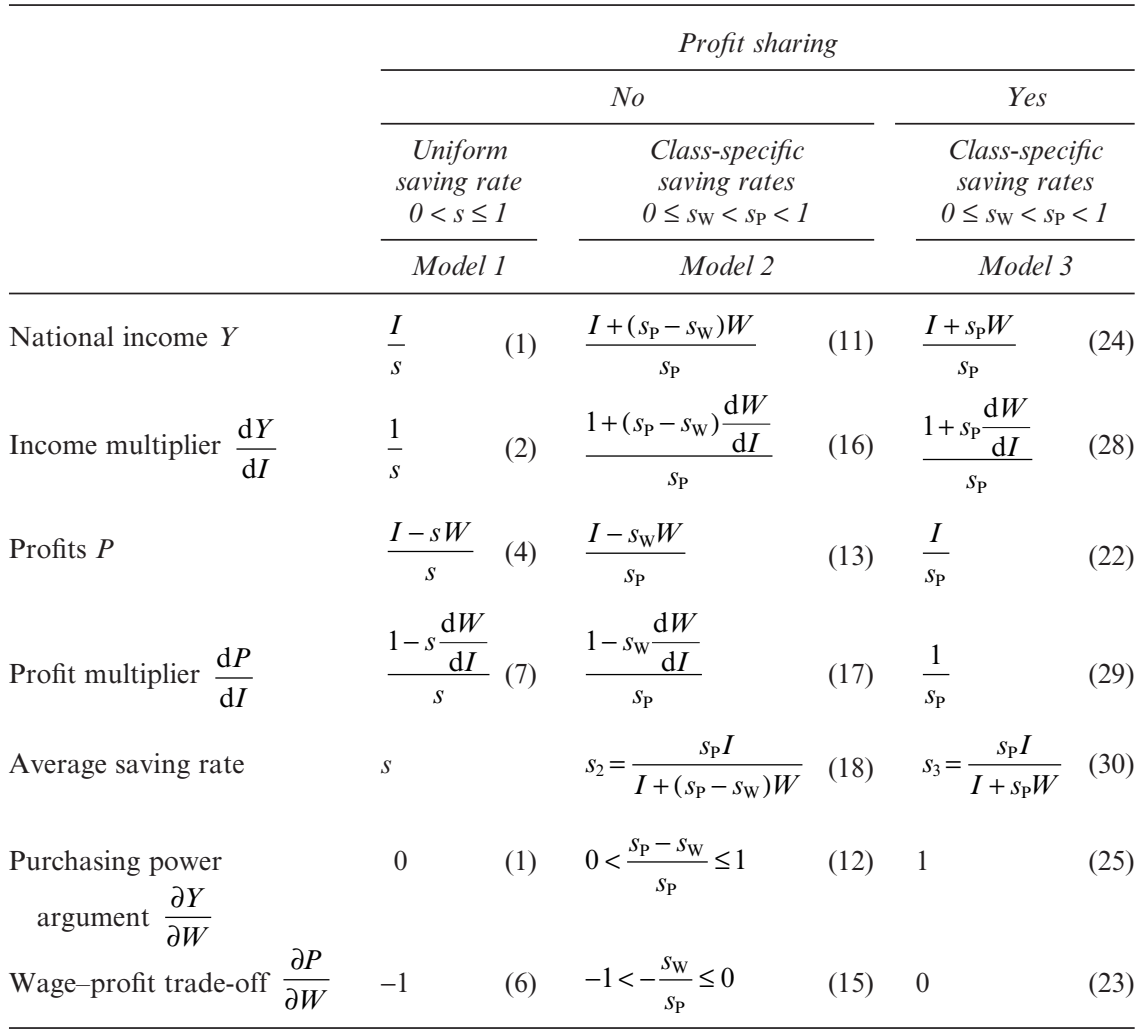


uniform saving rate excludes these interrelations. The sixth row demonstrates that the purchasing power argument gains ground when considering models $1-3$.

In the third scenario, a rising wage bill increases the national product by 100 per cent. At the same time, there exists no trade-off between the income categories: varying wages do not affect the level of profits. In model 3 , only the capitalists decide on this part of the domestic product. Thus, a profit-sharing system seems to be more receptive to an increment in wages.

Yet, the third arrangement bears conflict because profits have to be split among the parties. Differentiating equations (20) and (26) with respect to wages results in

$$
\frac{\partial P_{\mathrm{W}}}{\partial W}=\frac{s_{\mathrm{W}}}{S_{\mathrm{P}}-S_{\mathrm{W}}}=-\frac{\partial P_{\mathrm{P}}}{\partial W}
$$

Obviously, rising wages divert capitalists' income to the workers' profits. So the labour force enjoys higher earnings from both sources. In addition, for $0<s_{\mathrm{W}}<s_{\mathrm{P}}$ the comparison with equation (15) shows that the capitalists will suffer a more severe cutback in profits as opposed to a situation where profit sharing is missing.

Generally, fluctuations in autonomous demand alter the distribution. Then, the average saving rate varies too. This correspondence is invalidated only under two special premises: either a uniform propensity to consume is simply postulated for all levels of income or equation (9) is taken for granted, i.e. $\mathrm{d} W / \mathrm{d} I=W / I$ ensures constant income shares. However, theories concerning the determination of aggregate output and its development are wide of the mark as long as they are based on such counter-factual prerequisites.

In the absence of profit sharing, the assumptions of model 2 come closest to reality. If workers spend what they get, a higher pay raises national income by the same amount, while profits remain the same. Whenever employees save, an augmented remuneration is partly transmitted into an increasing domestic product. The rest has to be covered by profits. Of course, entrepreneurs steadily try to improve their earning potential by realizing labour-saving process innovations. Ceteris paribus, these efforts cause total wages to fall. Besides, domestic product may also decrease although profits rise.

At any rate, the insights gained result from the consideration of different saving rates. Therefore, one should be sceptical about that branch of macroeconomics which comes up without this crucial distinction.

\section{REFERENCES}

Ahmad, S. (1991). Capital in Economic Theory, Neo-classical, Cambridge and Chaos, Aldershot, Edward Elgar. 
Akerlof, G. A. (2007). 'The Missing Motivation in Macroeconomics', American Economic Review, Vol. 97, pp. 5-36.

Blanchard, O. (2003). Macroeconomics, 3rd edn, Upper Saddle River, NJ, Prentice Hall.

Blecker, R. A. (2002). 'Distribution, Demand and Growth in Neo-Kaleckian Macromodels', in M. Setterfield (ed.), The Economics of Demand-led Growth, Cheltenham, Edward Elgar, pp. 129-152.

Bortis, H. (1993). 'Notes on the Cambridge Equation', Journal of Post Keynesian Economics, Vol. 16, pp. 105-126.

Carlin, W. and Soskice, D. (2006). Macroeconomics, Oxford, Oxford University Press.

Chick, V. and Caserta, M. (1997). 'Provisional Equilibrium and Macroeconomic Theory', in P. H. Arestis, G. Palma and M. Sawyer (eds), Markets, Unemployment and Economic Policy, Essays in Honour of Geoff Harcourt, Vol. II, London, Routledge, pp. 223-237.

Harcourt, G. C. (2006). The Structure of Post-Keynesian Economics, Cambridge, Cambridge University Press.

Hein, E. (2006). 'On the (In-)stability and the Endogeneity of the "Normal" Rate of Capacity Utilization in a Post-Keynesian/Kalecki "Monetary" Distribution and Growth Model', Indian Development Review, Vol. 4, pp. 129-150.

Helmedag, F. (2005). 'Wechselwirkungen zwischen Verteilung, Verbrauchsverhalten und Volkseinkommen', in E. Hein, A. Heise and A. Truger (eds), Löhne, Beschäftigung, Verteilung und Wachstum, Marburg, Metropolis, pp. 41-58.

Kaldor, N. (1955/56). 'Alternative Theories of Distribution', Review of Economic Studies, Vol. 23, pp. 83-100.

Kalecki, M. (1942). 'A Theory of Profits', Economic Journal, Vol. 52, pp. 258-266.

Keynes, J. M. (1936). The General Theory of Employment, Interest and Money, in The Collected Writings of John Maynard Keynes, Vol. VII, London and Basingstoke, Macmillan/Cambridge, Cambridge University Press, 1978.

King, J. E. (2002). A History of Post Keynesian Economics Since 1936, Cheltenham, Edward Elgar.

Klär, E. and Slacalek, J. (2006). 'Entwicklung der Sparquote in DeutschlandHindernis für die Erholung der Konsumnachfrage', DIW Wochenbericht, Nr. 40/2006, pp. 537-543.

Lavoie, M. (1995). 'The Kaleckian Model of Growth and Distribution and its Neo-Ricardian and Neo-Marxian Critiques', Cambridge Journal of Economics, Vol. 19, pp. 789-818.

Mankiw, N. G. (2006). Macroeconomics, 6th edn, New York, Worth Publishers.

Pasinetti, L. (1962). 'Rate of Profit and Income Distribution in Relation to the Rate of Economic Growth', Review of Economic Studies, Vol. 29, pp. 267-279. 